\title{
THE CHALLENGES OF PROTECTING REFUGEES IN MIXED MIGRATION VIS-À-VIS THE APPLICATION OF ARTICLES 1F AND 31 OF THE REFUGEE CONVENTION*
}

\author{
Oghenerioborue Esther Eberechi \\ RN EkU, RM OAUTHC, PERIOP UBTH, LLB, LLM \\ UNIBEN, LLD \\ Solicitor and Advocate, Supreme Court of Nigeria, \\ Postdoctoral Fellow, The University of Fort Hare
}

\section{SUMMARY}

This article embarks on a critical analysis of the application of articles $1 \mathrm{~F}$ and 31 of the Refugee Convention in a mixed migration setting in Africa. It exposes the problem of mixed migration and how it affects refugees and offers a brief history and scope and purpose of these articles. This study argues that article $1 \mathrm{~F}(\mathrm{~b})$ is ambiguous and inadequate, and that it provides room for adjudicators to exclude certain migrants from refugee status. On the other hand, owing to vagueness in these articles, refugees can be penalised, criminalised and detained for possible extradition and repatriation. Additionally, refugees who enter countries of refuge amidst other migrants may find it difficult to report to an appropriate centre to apply for refugee status. Thus, they are not able to comply with article 31 of the Refugee Convention. Therefore, the author recommends the amendment of both articles 1F and 31 of the Refugee Convention to eliminate problematic ambiguities.

\section{INTRODUCTION}

Refugees who enter countries of refuge seeking asylum are sometimes excluded from protection under article 1F of the Convention Relating to the Status of Refugees (the Refugee Convention). ${ }^{1}$ Once excluded, they are frequently either detained contrary to article 31 of the Refugee Convention,

\footnotetext{
This article was a product of a poster presented at the 3rd Annual Conference, Refugee Law Initiative University of London 18-19 July 2018 on "Refugee Protection in a Hostile World? School of the Advanced Study | University of London, Malet Street, London WC1E 7HU, UK. Refugee Law Initiative School of the Advanced Study, University of London is therefore appreciated and acknowledged.

1 UN General Assembly, Convention Relating to the Status of Refugees, 28 July 1951, United
} Nations, Treaty Series, vol. 189, 137. 
given a limited time to leave the country, or are extradited to countries where their lives would be in danger of persecution. ${ }^{2}$ Like refugees who are victims of sexual violence, their cases may never reach a court. ${ }^{3}$ Other refugees who come undocumented into countries of refuge, and who in the midst of other migrants cannot present themselves to the required authority of a host country in compliance with the provision of article 31(1) of the Refugee Convention, may also be denied refugee status. Moreover, they may be labelled as criminals and detained contrary to the provision of article 31 of the Refugee Convention.

Mixed migration is a most problematic phenomenon of our time, especially in Africa, because it creates difficulties in identifying persons needing the protection of the Refugee Convention. ${ }^{4}$ In these cases, all migrants are considered defenceless at all stages of migration. However, not all migrants can benefit from the protection of the Refugee Convention. Thus, because of problems in identifying the groups of migrants needing protection as well as states' intolerance of illegal entry of foreigners into their countries and towards international crimes, some migrants who are genuinely in need of the protection of United Nations High Commissioner for Refugees (UNHCR) may be either excluded or penalised as illegal or undocumented migrants; and their applications for refugee status are therefore denied from time to time. Other challenges of protection identified in Africa include, among others, access to migrants (depending on the type of journey they undertake) and accessibility to information about the rights of refugees in certain countries.

The concept of mixed migration can be understood from two perspectives. First, it could arise from the various inspirations for migration and the various types of migrant who immigrate together using the same route, modes or means. Mixed migration has been defined as a "complex migratory population movement including refugees, asylum-seekers, economic migrants and other types of migrants as opposed to migratory population movements that consist entirely of one category of migrants". ${ }^{5}$ According to

2 The Refugee Appeal Board of South Africa v Mukungubila (185/2018) [2018] ZASCA 191 (19 December 2018).

3 Stevens and Eberechi "A Critical Analysis of Article 16 of the UN Refugee Convention in Relation to Victims of Sexual Violence in Refugee Camps in Africa" 2019 52(1) De Jure 166.

$4 \quad$ Long and Crisp "In Harm's Way: The Irregular Movement of Migrants to Southern Africa from the Horn and Great Lakes Regions" (2011) New Issues in Refugee Research Research paper no. 200; United Nations High Commissioner for Refugees, Geneva, Switzerland http://eprints.Ise.ac.uk/38311/ (accessed 2019-07-22).

5 European Commission "Asylum and Migration Glossary 6.0: A Tool For Better Comparability Produced by the European Migration Network" (May 2018) http://www.emncz.eu/emn-glossary-en-version.pdf (accessed 2018-01-10) 259; International Migration Law "Glossary on Migration" (2011) N²5 2ed IOM International Organisation for Migration http://www.corteidh.or.cr/sitios/Observaciones/11/Anexo5.pdf (accessed 2018-06-10) 63; International Migration Law "Glossary on Migration" (2004) IOM International Organisation for Migration http://www.iomvienna.at/sites/default/files/IML 1_EN.pdf (accessed 2018-06-10) 42; European Commission "Asylum and Migration Glossary 3.0: A Tool For Better Comparability Produced by the European Migration Network" (2014) http://extranjeros.empleo.gob.es/es/redeuropemigracion/glosario/emnglossary-en-version v30.pdf (accessed 2018-06-10) 197. 
available statistics, these migrants move from one country to another in Africa or from North Africa to Europe, although statistics are inaccurate. ${ }^{6}$

Mixed migrants may either decide to move deliberately or they may be forced to move; these migrants comprise individuals with diverse profiles and degrees of susceptibilities. They include "regular and irregular migrant workers, refugees, smuggled migrants, trafficked persons, unaccompanied minors, environmental migrants, stranded migrants and victims of exploitation and abuse". 7 Occasionally, some of them employ the use of illegitimate routes to escape from "political unrest, persecution, and conflict", while others flee from drought, crop failure, food insecurity, and severe poverty either in the host and transit states with little or no protection and consequently they are exposed to human rights abuse. ${ }^{8}$

For any migrant to enjoy international protection as a refugee, the individual must have suffered certain maltreatment as provided for in article 1 of the Refugee Convention. This implies that not all migrants in mixed migration can be protected as refugees. Alfaro-Velcamp and Shaw aver that some African immigrants who immigrate into certain countries in Africa do so without permits/documentation ${ }^{9}$ and are therefore perceived as law breakers and are frequently tagged as "refugees" ${ }^{\text {"10 }}$ contrary to the legal definition of refugee. ${ }^{11}$ This perception is problematic for refugees because they are grouped together with other migrants.

Persons who require the protection of the Refugee Convention are often regarded as criminals alongside other undocumented mixed migrants who are subjected to arrest and then automatically detained and apprehended as illegal immigrants, contrary to the provision of article $1 \mathrm{~F}$ of the Refugee Convention. Furthermore, there are limited reception centres in some countries $;{ }^{13}$ refugees entering a country may have difficulty accessing reception centres; this may take days or weeks. In the process, they are sometimes arrested, tagged as illegal migrants and detained for repatriation, contrary to article 31 of the Refugee Convention.

This study examines the application of articles $1 \mathrm{~F}$ and 31 of the Refugee Convention in a mixed migration setting in Africa. It uncovers the problem of mixed migration and how it affects refugees. It offers a brief history, scope and purpose of the articles. "Africa is in the global south, comprising 54

6 Mixed Migration Centre "Mixed Migration Review 2018 Highlights Interviews Essays Data" (2018) http://www.mixedmigration.org/ (accessed 2019-07-22).

7 Njuki and Abera "Forced Displacement and Mixed Migration Challenges in the IGAD Region" 2018 7(1) Great Insights Magazine 11; UN Office for the Coordination of Humanitarian Affairs (OCHA) "Mixed Migration in Southern Africa" https://reliefweb.int/sites/reliefweb.int/files/resources/OCHA_ROSA_Humanitarian_Bulletin_ Jan_204.pdf (accessed 2019-07-15).

8 Ibid.

9 MHub Conditions and Risks of Mixed Migration in North East Africa Study 2 (2015).

10 Alfaro-Velcamp and Shaw "'Please GO HOME and BUILD Africa': Criminalising Immigrants in South Africa" 2016 42(5) Journal of Southern African Studies 983985.

S 3 of the Refugees Act 130 of 1998; Art 1 of the Refugee Convention.

12 Alfaro-Velcamp and Shaw 2016 Journal of Southern African Studies 985.

13 Ibid. 
countries $^{14}$ with a population of $1,321,384,450$ as at 16 July 2019 and is equivalent to $16.64 \%$ of the total world population". ${ }^{15}$ Africa is championed by its regional body, the African Union.

The continent is further divided into eight sub-regional bodies - namely, the Arab Maghreb Union (AMU/UMA) and the Community of Sahel-Saharan States (CENSAD) in the north; the Economic Community of West African States (ECOWAS) located in the west; the East African Community (EAC) and the Intergovernmental Authority on Development (IGAD) in the east; the Common Market for Eastern and Southern Africa (COMESA) in the southeast; the Economic Community of Central African States (ECCAS) in the centre; and the Southern African Development Community (SADC) in the south. ${ }^{16}$ With regard to the status of the Refugee Convention and the 1967 Protocol, 49 countries in Africa have ratified either one or both of the Convention and the Protocol, as documented on April 2015; Madagascar has ratified only the 1951 Convention while Cape Verde has only ratified the 1967 Protocol. $^{\text {P }}$

\section{AN APPRAISAL OF THE APPLICATION OF ARTICLES $1 F$ AND 31 OF THE REFUGEE CONVENTION}

\section{Article 1F}

Article $1 \mathrm{~F}$ of the Refugee Convention provides the grounds for exclusion from refugee status. It reads:

"The provisions of this Convention shall not apply to any person with respect to whom there are serious reasons for considering that:

(a) he has committed a crime against peace, a war crime, or a crime against humanity, as defined in the international instruments drawn up to make provision in respect of such crimes;

(b) he has committed a serious non-political crime outside the country of refuge prior to his admission to that country as a refugee;

(c) he has been guilty of acts contrary to the purposes and principles of the United Nations".

Article 1F functions to protect contracting states' security and prohibits individuals with certain demeanour from benefitting from the protection of the Refugee Convention. ${ }^{18}$ It is also meant to prevent criminal justice deserters

14 Worldometer "How Many Countries in Africa?" (2019) https://www.worldometers.info/ geography/how-many-countries-in-africa/ (accessed 2019-07-16).

15 Worldometer "Population of Africa (2019)" (July 2019) https://www.worldometers.info/worldpopulation/africa-population/ (accessed 2019-07-16).

16 Office of the Special Adviser on Africa "The Regional Economic Communities (RECs) of the African Union” United Nations http://www.un.org/en/africa/osaa/peace/recs.shtml (accessed 2019-07-16).

17 UNHCR United Nations High Commissioner for Refugees "States Parties to the 1951 Convention Relating to the Status of Refugees and the 1967 Protocol" (April 2015) https://www.unhcr.org/protect/PROTECTION/3b73b0d63.pdf (accessed 2019-07-16) 1.

18 Zimmermann and Wennholz The 1951 Convention Relating to the Status of Refugees and Its 1967 Protocol: A Commentary (2011) 583. 
from enjoying international refugee protection, thereby guarding the security of host countries. ${ }^{19}$ Article $1 \mathrm{~F}$ is also a prerequisite for the elimination of certain persons from international refugee protection. Other objects of article $1 \mathrm{~F}$, as enunciated in the travaux préparatoires, ${ }^{20}$ are to protect the sanctity of the refugee status system against exploitation - by excluding offenders of crimes and by curbing the impunity of those who profit from refugee status and contribute to refugee production. ${ }^{21}$ In addition, article $1 \mathrm{~F}$ was created to hold accountable perpetrators of grievous crimes in the Second World War, as well as criminals of a non-political nature or persons convicted of acts contrary to the principles of the United Nations (UN). The scope of articles $1 \mathrm{~F}(\mathrm{a})$ and $(\mathrm{c})$ is clearly delineated.

However, article $1 \mathrm{~F}(\mathrm{~b})$ does not define the categories of crime that should be categorised as "serious non-political crime outside the country of refuge prior to his admission to that country as a refugee". Can article $1 \mathrm{~F}(\mathrm{~b})$ mean to imply all serious non-political crimes committed as defined by the criminal laws of the domestic judicial systems? The significance of article $1 \mathrm{~F}(\mathrm{~b})$ is that the mere commission of a crime will suffice, irrespective of whether conviction or punishment has been imposed or whether the criminal has served a jail term, although the commission of a crime can be inferred from prosecution of an applicant for refugee status. The threshold of the burden of proof here is not beyond a reasonable doubt but there should be a "reasonable belief" that an asylum applicant committed the crime. ${ }^{22}$ The author submits that this provision gives contracting parties ample discretion to determine crimes that could fit into this category. This is because there will be variations in determining what constitutes a non-political crime by host states.

A serious non-political crime is described as an act that covers a broad spectrum of crimes committed by an individual with personal mens rea for

9 Ibid.

20 UN Conference of Plenipotentiaries on the Status of Refugees and Stateless Persons, Conference of Plenipotentiaries on the Status of Refugees and Stateless Persons: Summary Record of the 24th Meeting, 27 Nov. 1951, UN doc. A/CONF.2/SR.24, Statements of Herment (Belgium) and Hoare (UK) http://www.refworld.org/cgibin/texis/vtx/rwmain?page=printdoc\&docid=3ae68cde18 (accessed 2018-09-27); GoodwinGill The Refugee in International Law (1996) 95-114, 147-50; Shah "Taking the 'Political' out of Asylum: The Legal Containment of Refugees' Political Activism" in Nicholson and Twomey (eds) Refugee Rights and Realities: Evolving International Concepts and Regimes (1999) 119 130; Gilbert "Current Issues in the Application of the Exclusion Clauses" in Feller, Turk and Nicholson (eds) Refugee Protection in International Law: UNHCR's Global Consultations on International Protection (2003) 427; Dogar The Purpose of the Exclusion Clause and the Role of the UNHCR: Protection or Impunity? (LLM thesis, McGill University, Montreal) 2015.

21 Zimmermann and Wennholz The 1951 Convention Relating to the Status of Refugees and Its 1967 Protocol: A Commentary 583; Larsaeus, "The Relationship Between Safeguarding Internal Security and Complying with International Obligations of Protection. The Unresolved Issue of Excluded Asylum Seekers" 20047369 Nordic Journal of International Law 69; UN High Commissioner for Refugees (UNHCR) "Guidelines on Protection: Application of the Exclusion Clauses: Article IF of the 1951 Convention relating to the Status of Refugees" (HCR/GIP/03/05, 4 Sept. 2003) 2; Gilbert in Feller, Turk and Nicholson Refugee Protection in International Law 425; Standing Committee of the Executive Committee of the High Commissioner's Programme, "Note on the Exclusion Clauses", 47th Session, UN doc. EC/47/SC/CRP.29, 30 May 1997 par 3.

22 Gavrić v Refugee Status Determination Officer, Cape Town [2018] ZACC 38 par 107, 110. 
selfish benefits devoid of political incentives. ${ }^{23}$ Where there is no nexus between a crime and a political purpose, that crime can be regarded as nonpolitical. The African Union statute on refugee protection does not outline the species of crime that could be denoted as non-political, but provides for the exclusion from protection of persons who are offenders of such crimes. ${ }^{24}$ However, states in Africa vary widely in their definition of a non-political crime, and some do not offer any clarification of such crimes in their refugee law.

For instance, the Ugandan refugee law declares a non-political crime to be a crime devoid of political disposition; it excludes hostility against a state regime relating to a question of political leadership or governance of a nation state or criminalities that are not interrelated to, or are a fragment of, a political disturbance that is executed as a political association agenda or an opposition group struggling for supremacy or political dominance of a nation. ${ }^{25}$ Likewise, the South African Refugees Act describes a serious nonpolitical crime as any crime that is "punishable by imprisonment" under its criminal regime. ${ }^{26}$ A serious non-political crime has been designated in Namibia to include "any non-political offence which, if committed in Namibia, would be punishable with a sentence of imprisonment or other form of deprivation of liberty for a period of five years or more". ${ }^{27}$ This implies that crimes that are punishable with five years' imprisonment or house arrest could be used to deprive a person of refugee status in Namibia. In the same way, the Zambian Refugee Act declares a serious non-political crime to be an "offence" that is acknowledged by domestic law as a felony or, if not declared to be a misdemeanour, is punishable, without "proof of previous conviction, with death, or with imprisonment with hard labour for three years or more" under section 4 of the Penal Code. ${ }^{28}$

Conversely, the Ghanaian Refugee Act, ${ }^{29}$ the Kenyan Refugee Act, ${ }^{30}$ the Nigerian National Commission for Refugees Act, ${ }^{31}$ the Ethiopian Refugee law $^{32}$ and the Tanzanian Refugee Act $^{33}$ do not categorise crimes that could be considered as serious non-political crimes. Interestingly, Morocco,

23 UN High Commissioner for Refugees (UNHCR) Guidelines on International Protection No. 5: Application of the Exclusion Clauses: Article 1F of the 1951 Convention Relating to the Status of Refugees in Handbook and Guidelines on Procedures and Criteria for Determining Refugee Status Under the 1951 Convention and the 1967 Protocol Relating to the Status of Refugees (December 2011) HCR/1P/4/ENG/REV. 3 par 15 https://www.Refworld.org/docid/ 4f33c8d9 2.html (accessed 2019-06-17).

24 Art $4(\mathrm{~F})$ and $5(\mathrm{~B})$ of the OAU Convention Governing the Specific Aspects of Refugee Problems in Africa, adopted on 10 September 1969 by the Assembly of Heads of State and Government. CAB/LEG/24.3. It entered into force on 20 June 1974.

$25 \mathrm{~S} 2$ of the Refugees Act 21 of 2006 (Uganda).

$26 \mathrm{~S} 4(1)(b)$ of the Refugees Act 130 of 1998 (South Africa).

27 S 41(b)(ii) and 3 of the Namibia Refugees (Recognition and Control) Act 2 of 1999 (Namibia).

28 S 2 of the Refugees Act 1 of 2017 (Zambia); S 4 of the Penal Code Act Cap 87 of the Laws of Zambia.

$S 1(2)(b)$ of the Refugee Law of 1992 (Ghana).

S 4(b)(c) of the Refugees Act 13 of 2006 (Kenya).

1 National Commission for Refugees Act (Nigeria), Cap N21 LFN 2004, 29 December 1989.

32 Ethiopia: Proclamation No.1110/2019, 27 February 2019.

33 The Refugee Act 9 of 1998 (Tanzania). 
Tunisia and Egypt are yet to domesticate the 1951 UN Refugee Convention. However, the right to seek asylum is provided for in article 26 of the Tunisian Constitution, ${ }^{34}$ and in article 57 of the Constitution of the Arab Republic of Egypt ${ }^{35}$ while the Moroccan Constitution does not provide for the protection of refugees. ${ }^{36}$ Additionally ${ }_{37}$ in Egypt, refugee status determination is adjudicated by the UNHCR. ${ }^{37}$

The issue of a non-political crime ${ }^{38}$ was raised in Gavrić v Refugee Status Determination Officer, Cape Town. ${ }^{39}$ Gavrić, a Serbian citizen, had been in the police service of that country before being detained, charged and later subjected to house arrest for the murders of Mr Zeljo Ražnatović (popularly termed as Arkan) and his two "bodyguard" in Belgrade, Serbia, before escaping to South Africa with a different identity in $2007 .{ }^{40}$ In 2008 , while residing in South Africa, he was convicted in his absence of the murders and sentenced to 30 years in prison (later increased to 35) by the Serbian Supreme Court; ${ }^{41}$ an extradition order by the Serbian Ministry of Justice was served on South Africa in $2011 .{ }^{42}$

While in South Africa, Gavrić was also a victim and witness to unlawful gunfire and was later arrested and charged with illicit possession of drugs and the illegal acquisition of a driver's licence, passport and even firearms with a deceitful name. ${ }^{43}$ After residing in South Africa for four years, he sought asylum here in order to avert the extradition order and his repatriation to Serbia under section 3 of the Refugee Act. ${ }^{44}$ His application for refugee status was denied by the Refugee Status Determination Officer (RSDO) and he was excluded from protection as a refugee in accordance with section $4(1)(b)$ on the ground that he had been convicted of a serious non-political crime. ${ }^{45}$ Dissatisfied, Gavrić appealed against the decision of the RSDO to the High Court and asked the court to affirm that section 4(1)(b) of the South African Refugees Act was constitutionally unenforceable; he requested the court to outlaw the expulsion order and prevent his repatriation to Serbia ${ }^{46}$ since it violated his constitutional "right to life, dignity, equality and security of person". ${ }^{47}$ This appeal was dismissed with costs and the appeal also failed at the High Court full bench. ${ }^{48}$

34 Tunisia's Constitution of 2014.

5 The Constitution of The Arab Republic of Egypt 2014

36 Morocco's Constitution of 2011.

37 Art 2(a) of the 1954 Memorandum of Understanding between the Egyptian Government and the UNHCR.

38 Art $1 \mathrm{~F}(\mathrm{~b})$ of the Refugee Convention; s 4(1)(b) of the Refugees Act 130 of 1998 (South Africa).

39 Gavrić v Refugee Status Determination Officer, Cape Town supra.

40 Gavrić v Refugee Status Determination Officer, Cape Town supra par 3, 5, 6, 7.

41 Gavrić v Refugee Status Determination Officer, Cape Town supra par 8.

42 Gavrić v Refugee Status Determination Officer, Cape Town supra par 9.

43 Ibid.

44 Gavrić v Refugee Status Determination Officer, Cape Town supra par 10.

45 Gavrić v Refugee Status Determination Officer, Cape Town supra par 10; Refugees Act 130 of 1998.

46 Gavrić v Refugee Status Determination Officer, Cape Town supra par 11.

47 Gavrić v Refugee Status Determination Officer, Cape Town supra par 20.

48 Gavrić v Refugee Status Determination Officer, Cape Town supra par 11-12. 
His application to the Supreme Court of South Africa for leave to appeal against the decision of the RSDO and that of the High Court was also denied. $^{49}$ However, at the Constitutional Court, at issue was the constitutionality of section 4(1)(b) of the South African Refugees Act. The court held it was not unconstitutional because section 2, which provides for non-expulsion, improvises for whatever constitutional gap might have existed. ${ }^{50}$ In deciding the constitutionality of section 4 of the Refugees Act, the court cited the Supreme Court of Appeal case, Minister of Home Affairs v Watchenuka:

"Human dignity has no nationality. It is inherent in all people - citizens and non-citizens alike - simply because they are human. And while that person happens to be in this country - for whatever reason - it must be respected, and is protected, by $\mathrm{s} 10$ of the Bill of Rights.'

This implies that, once individuals are in the territory, their right to human dignity is protected. In addition, it entails that a person who is excluded from protection under the Refugees Act has the right to remain in South Africa if extradition would lead to the loss of his or her right to life. ${ }^{52}$ It was further established by the court that there are no exceptions in South Africa to a person's right to life, human dignity and not to be treated or punished in a cruel, inhumane or humiliating manner. ${ }^{53}$

In determining the applicant's refugee status, the court pointed to a procedural defect in which the RSDO only provided the conclusion of the adjudication to the applicant but failed to disclose the logical reasoning behind the denial of the status. ${ }^{54}$ Moreover, the RSDO did not ascertain whether the crime was political. ${ }^{55}$ The Constitutional Court accordingly set aside the decision of the RSDO. However, it is well known that most cases involving refugees do not reach court. ${ }^{56}$ Therefore, many asylum seekers whose applications are rejected by the RSDO may not be as lucky as Gavrić as to have their cases determined in court.

The Constitutional Court of South Africa also investigated whether the applicant should be excluded, in accordance with section $4(1)(b)$ of the

49 Gavrić v Refugee Status Determination Officer, Cape Town supra par 12.

50 Gavrić v Refugee Status Determination Officer, Cape Town supra par 22, 31; Refugees Act 130 of 1998.

51 Minister of Home Affairs $v$ Watchenuka [2003] ZASCA 142; 2004 (4) SA 326 (SCA) 330B par 25.

52 Mohamed $v$ President of the Republic of South Africa (Society for the Abolition of the Death Penalty in South Africa and Another Intervening) 2001 (3) SA 893 (CC) par 37-39; Minister of Home Affairs v Tsebe [2012] ZACC 16; 2012 (5) SA 467 (CC); 2012 (10) BCLR 1017 (CC) (Tsebe) par 43.

53 Minister of Home Affairs $v$ Tsebe supra par 50.

54 Gavrić v Refugee Status Determination Officer, Cape Town supra par 69.

55 Ibid.

56 People Opposing Women Abuse (POWA) with the AIDS Legal Network (ALN) on behalf of the One in Nine Campaign and the Coalition for African Lesbians (CAL) 2010 "Criminal Injustice: Violence against Women in South Africa", Shadow Report on Beijing + 15 March 2010 https://tbinternet.ohchr.org/Treaties/CEDAW/Shared\%20Documents/ZAF/INT CE DAW_NGO_ZAF_48_10364_E.pdf 12 (accessed 2020-07-27); Eberechi "Access to Justice for Victims of Sexual Violence in Refugee Camps" (Unpublished LLD Thesis 2018 University of Pretoria) https://repository.up.ac.za/handle/2263/6 6657/statistics 226 (accessed 2020-07-27). 
Refugees Act, from the Act's protection based on his commission of a serious non-political crime. The court began by isolating the principles and criteria for the identification of a political crime. The court said that for a crime to be considered political there must be an obvious connection between the criminal act and its political intention. The said act must be proportional to its political purpose. ${ }^{57}$ The crime must have been committed with an obvious and sincere political motivation for a specific purpose and not for private benefit. ${ }^{58}$ In addition, the political interest must be palpable to any rational human being. ${ }^{59}$ Political crimes were also identified by virtue of their association with "specific events and time". ${ }^{60}$ For instance, offences considered as political in Senegal consist of crimes committed (in Senegal or a foreign country) between 1 January 1983 and 31 December 2004 in connection with "the general or local elections" or committed with political incentives, whether the offenders have been found guilty or not. ${ }^{61}$

The Constitutional Court added that the political objective must be for the defence and advancement of "fundamental human rights" - namely, the "right to life, equality, human dignity, political" involvement, with no discrimination because of sex or race. ${ }^{62}$ The political purpose must protect and promote "the rule of law", liberty of individuals, faith, "beliefs", views, expression, principles, and the establishment of an open and autonomous social order. ${ }^{63}$ In the instant case, in deciding whether the felony committed by the applicant was non-political, the court considered foreign judgments that were against the applicant, but did not rely on them. Tactically, Gavrić could not convince the court that the crime was political, and he was therefore excluded from refugee status under section $4(1)(b){ }^{6}$

Article $1 \mathrm{~F}(\mathrm{~b})$ was similarly challenged in Febles $v$ Canada (Citizenship and Immigration). ${ }^{65}$ Febles was a Cuban whose refugee status had been revoked; he had been served with an expulsion order by the United States (US) after serving two jail terms for the crime of assault with the use of deadly weapons - in the first instance by striking his roommate's head with a hammer, and secondly for threatening the life of the roommate's girlfriend at knifepoint. ${ }^{66}$ Febles escaped to Canada to apply for refugee status but was denied such protection, in accordance with article $1 \mathrm{~F}(\mathrm{~b})$ of the Refugee

57 Tribunal Administratif Fédéral, Case E-7772, 22 June 2007 par 4.4; Gavrić v Refugee Status Determination Officer, Cape Town supra par 98.

58 Tribunal Fédéral, case ATF 106 lb 307.

59 Tribunal Fédéral, case ATF supra.

$60 \mathrm{~S} 20(2)(3)$ of the Promotion of National Unity and Reconciliation Act 34 of 1995 (Reconciliation Act): Art 44-45 of Ordonnance $\mathrm{n}^{\circ}$ 06-01 du 28 Moharram 1427 correspondant au 27 février 2006 portant mise en oeuvre de la Charte pour la paix et la réconciliation nationale (English translation; Ordinance No. 06-01 of 28 Moharram 1427 corresponding to 27 February 2006 implementing implementation of the Charter for Peace and National Reconciliation).

61 FIDH v Senegal par 2, Comm. 304/2005, 21st ACHPR AAR Annex II (2006-2007).

62 Gavrić v Refugee Status Determination Officer, Cape Town supra par 106.

63 Ibid.

64 Refugees Act 130 of 1998; Febles v Canada (Citizenship and Immigration) 2014 SCC 68 [2014] 3 S.C.R. 431.

65 Febles v Canada 432, 467 (73).

66 Febles v Canada supra 432, 468 (77-78). 
Convention ${ }^{67}$ and sections 98 of the Immigration and Refugee Protection Act (IRPA) of Canada, based on the crime committed prior to his flight from the US. ${ }^{68}$ The overarching issue the court had to address was the interpretation of article $1 \mathrm{~F}(\mathrm{~b})$ of the Refugee Convention and whether it included "matters or events after commission of crime" - for instance whether the applicant is a "fugitive from justice or unmeritorious or dangerous at the time of the application for refugee protection" ${ }^{69}$ or if an applicant who has served a jail term for the conviction of a serious crime or "because of redeeming his conduct in the interim" is qualified for refugee protection. ${ }^{70}$

The Federal Court and Federal Court of Appeal, dismissed Febles's appeal against the refugee board's decision that the crime fell within the ambit of article $1 \mathrm{~F}(\mathrm{~b})$ of $1951 \mathrm{UN}$ Refugee Convention and section 98 of IRPA and, therefore, did not qualify for international protection as a refugee. ${ }^{71}$ Although the Supreme Court of Canada, allowed the appeal Feble's appeal and referred the case back to the Immigration and Refugee Board for redetermination. ${ }^{72}$ However, the Febles case is a classic example of the ambiguous nature of article $1 \mathrm{~F}(\mathrm{~b})$; the court had to determine the outcome of an issue that was outside the conception of article $1 \mathrm{~F}(\mathrm{~b})$ as introduced by the parties to the suit. During the proceedings, issues like remorse, redemption of conduct, and the serving of jail terms were raised. ${ }^{73}$ Febles also argued that article $1 \mathrm{~F}(\mathrm{~b})$ only applies to absconders of crimes and not to persons who have already been punished for the crimes committed. These were extraneous issues argued in the proceedings. The author therefore contends that there is a need to amend article $1 \mathrm{~F}(\mathrm{~b})$ to reflect the arguments raised in the case of Febles.

The joint cases of Bundesrepublik Deutschland $v B$ and $D^{74}$ are further classic examples of the abstruse nature of the provisions of article $1 \mathrm{~F}(\mathrm{~b})$ of the Refugee Convention. Here, the German courts were uncertain whether membership or support of terrorist groups could constitute an apolitical crime. B (in Case C-57/09) was a Turkish citizen of Kurdish descent, who was arrested, tortured and sentenced to life imprisonment for his support of guerrilla armed conflict. ${ }^{75}$ While in prison, he murdered a fellow suspected inmate for snitching, which earned him another life sentence. He later escaped to Germany, capitalising on his conditional release for six months on health grounds. There he applied for refugee protection and the prohibition of extradition to Turkey. ${ }^{76}$ However, both applications fell through because the Bundesamt felt that he had committed a non-political crime in

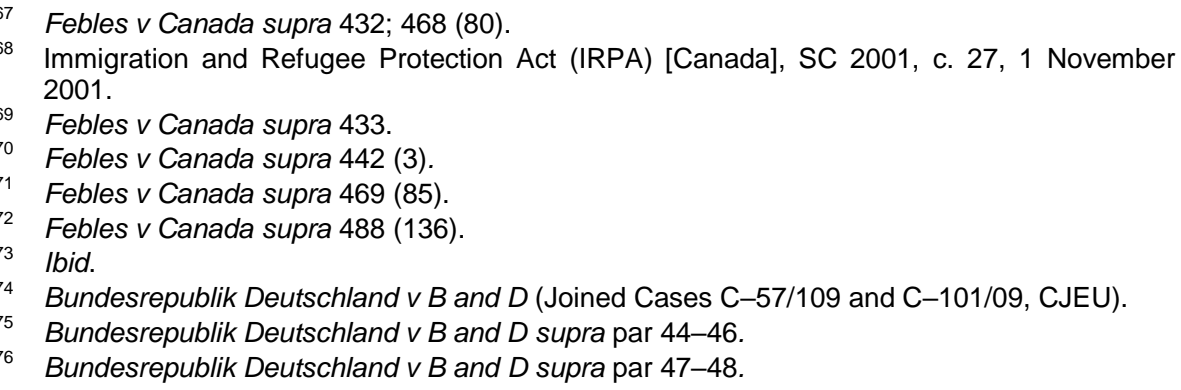


violation of Paragraph 3(2)(2) of the Germany: Asylum Procedure Act $(\text { AsyIVfG })^{77}$ and that he was therefore not immune to extradition to Turkey. ${ }^{78}$

On appeal to the Administrative Court, Gelsenkirchen (Verwaltungsgericht Gelsenkirchen), this decision was invalidated and the Administrative Court outlawed the extradition of B to Germany and ordered that B should be granted refugee status. ${ }^{79}$ The Bundesamt appeal to the Higher Administrative Court of North Rhine-Westphalia (the Oberverwaltungsgericht für das Land Nordrhein-Westfalen) against the decision of the lower court was terminated because the Oberverwaltungsgericht reasoned that the aim of the exclusion clause was not just to punish perpetrators of serious nonpolitical crime but was also intended to prevent an applicant from extradition to a country where they would be at risk of persecution; thus a holistic approach to such a decision must be adopted with the doctrine of "proportionality" in mind. ${ }^{80}$ The Higher Administrative Court also reasoned that exclusion should be considered when the applicant constitutes a threat to the security of the country. ${ }^{81}$

Dissatisfied, the Bundesamt appealed against the judgment of the Higher Administrative Court to the Federal Administrative Court (the Bundesverwaltungsgericht) where they contended that exclusion from protection under Paragraph 60(8) of the Aufenthaltsgeset $z^{82}$ and paragraph 3(2) of the Asylum Procedure Act ${ }^{83}$ (for the purpose of this article) does not require a refugee not to be a threat to the peace and security of Germany and that the issue of proportionality does not arise in this case. ${ }^{84}$ The Bundesamt also maintained that article 12(2) of Directive 2004/83 cannot be suspended by members of the European Union. ${ }^{85}$

Equally, D (in Case C-101/09), who is of the same nationality and ethnicity as $\mathrm{B}$, confessed that he was a guerrilla fighter and a senior officer of PKK; he had been sent to the northern part of Iran but only resided there for about a year. He left the PKK due to political ideological differences and leadership and subsequently escaped to Germany as a result of a threat to his life. ${ }^{86} \mathrm{He}$ was granted asylum status under the existing law of 2001. However, with the advent of the Terrorismusbekämpfungsgesetz (Anti-Terrorism File Act), ${ }^{87}$ the

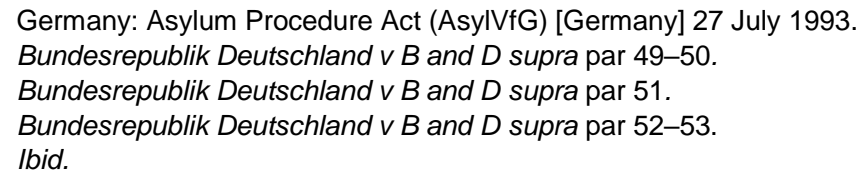

85 Bundesrepublik Deutschland $v B$ and $D$ supra par 54; European Union: Council of the European Union, Council Directive 2004/83/EC of 29 April 2004 on Minimum Standards for the Qualification and Status of Third Country Nationals or Stateless Persons as Refugees or as Persons Who Otherwise Need International Protection and the Content of the Protection Granted, 30 September 2004.

86 Bundesrepublik Deutschland $v B$ and $D$ supra par 57-59.

87 Anti-Terrorism File Act of December 22, 2006 (Federal Law Gazette I p. 3409), which was last amended by Article 10 of the Law of August 14, 2017 (Federal Law Gazette I p. 3202). 
Bundesamt reviewed the grant of asylum and withdrew his protection as a refugee in accordance with paragraph 73(1) of the Asy/VfG, ${ }^{88}$ on the basis that he had committed a serious non-political crime outside of Germany before the status was granted. ${ }^{89}$ On appeal to the Administrative Court, Gelsenkirchen, the decision of the Bundesamt was likewise overturned. In the same vein, the Bundesamt appealed to the Higher Administrative Court of North Rhine-Westphalia where the matter was dismissed on the same grounds as in the case of $B$ in 2007, and the court reasoned that the exclusion clause under the German law did not apply. ${ }^{90}$

The Bundesamt, being unhappy with the decision of the Higher Administrative Court, sought the Federal Administrative Court to review the appeal court decision. ${ }^{91}$ The Federal Administrative Court found that B and $D$ qualified for refugee protection because they would be at risk of persecution if they were repatriated to Turkey. However, neither applicant could enjoy refugee protection since they met the requirement for exclusion as provided for under article $12(2)$ of Directive 2004/83. ${ }^{92}$ The Federal Administrative Court reiterated that whether the exclusion clauses are applicable in the instant cases under article 16(a) of the Grundgesetz (Germany: Basic Law for the Federal Republic of Germany). ${ }^{93} B$ and $D$ cannot be excluded, this implied that there is a conflict between the provision of Grundgesetz and article12(2) of Directive 2004/83. Therefore, the cases were referred to the European Court of Justice for their interpretation.

Several questions were submitted by the German court to the European court. First, does former membership, and participation as fighter and officer of a prohibited terrorist group create a non-political crime? ${ }^{94}$ Secondly, if this is a non-political crime, then does the exclusion clause in article 12(2)(b) and (c) require that the asylum seeker must constitute an incessant threat to the peace of the country? ${ }^{95}$ Thirdly, is the proportionality test required in determining application of the exclusion clause? Fourthly, if proportionality is considered in the third question, should it be considered in extradition proceedings under article 3 of European Convention on Human Rights $(\mathrm{ECHR})^{96}$ or under state laws and is exclusion disproportionate only in exceptional cases having particular characteristics? ${ }^{97}$ Lastly, is there a conflict between the provision of "Directive 2004/83, for the purposes of Article 3 [of Directive 2004/83] and National law" even if an asylum seeker qualifies to be excluded in accordance with article 12(2) of the Directive while possessing "a right to asylum under national constitutional law" as in

\footnotetext{
Germany: Asylum Procedure Act; Bundesrepublik Deutschland v B and D supra par 60. Bundesrepublik Deutschland $v B$ and $D$ supra par 60. 
the case of $\mathrm{B} ?^{98}$ In addition, is there a conflict if the asylum seeker is still recognised as a holder of a right to asylum under domestic "constitutional law", despite the fact that he satisfies "one of the exclusion criteria laid down in Article 12(2) of the directive" and refugee status under article 14(3) of the directive is accordingly revoked, as in the case of $D$ ? $^{99}$

It was held that membership of and participation in a terrorist group that is listed in the Annex to Common Position $2001 / 931^{100}$ does not necessarily constitute a non-political crime on the part of an asylum seeker, and that individual responsibility for the crime must be established in order to prove the provision of article 12(2) of Directive 2004/83. ${ }^{101}$ On the second question, the court concluded that posing a threat to the peace and security of a receiving state is not a criterion for excluding an asylum seeker under article $12(2)$ of the Directive. ${ }^{102}$ In addition, there is no need for the proportionality test in determining exclusion in this case. ${ }^{103}$ Finally, the European Court declared that states have the right to grant asylum under their domestic law, but the grant must be distinct from providing refugee status under the directives.

The problem with this clause is that states are given a wide discretion to determine the scope and types of crime that are deemed to be non-political, which can cause hardships for seekers of refugee status. As seen above, contracting states vary as to what they deem to be non-political crimes. However, the court in Gavrić did not outline offences that can be regarded as non-political but gave the conditions and principles that the RSDO and courts should look out for, since what constitutes a non-political crime in one country will not be so in another country. Also, in the Gavric case, the RSDO relied on the Serbian judgment in arriving at her decision, even though the burden of proof was reasonable acceptance that the applicant committed the crime. In the Febles case, as stated above, issues fell outside the purview of reasonable belief. However, in Bundesrepublik Deutschland $v B$ and $D$, it was held that lending support or belonging to a terrorist group does not necessarily constitute a non-political crime, unless individual culpability of the asylum seeker can be established. ${ }^{105}$ Once an applicant in some jurisdictions is excluded from refugee status by a court, the applicant can be

98 Ibid.

99 Ibid

100 The Council of the European Union "Council Common Position of 27 December 2001 on the Application of Specific Measures to Combat Terrorism" (2001/931/CFSP) Official Journal of the European Communities L 344/94, 28.12.2001.

101 Bundesrepublik Deutschland v B and D supra par 99; UN High Commissioner for Refugees (UNHCR), UNHCR public statement in relation to cases Bundesrepublik Deutschland $v B$ and $D$ pending before the Court of Justice of the European Union (July 2009) https://www.refworld.org/docid/4a5de2992.html (accessed 2019-12-20) 7.

102 Bundesrepublik Deutschland $v B$ and $D$ supra par 105; UN High Commissioner for Refugees (UNHCR) UNHCR public statement in relation to cases Bundesrepublik Deutschland $v B$ and $D$ pending before the Court of Justice of the European Union 32-33.

103 Bundesrepublik Deutschland $v B$ and D supra par 111.

104 Bundesrepublik Deutschland v $B$ and D supra par 121.

105 UN High Commissioner for Refugees (UNHCR) UNHCR public statement in relation to cases Bundesrepublik Deutschland $v B$ and $D$ pending before the Court of Justice of the European Union 30. 
declared an illegal immigrant and thus article $31^{106}$ can be invoked. However, there may be provisions in the national laws such as article 16(a) of the Grundgesetz (Germany: Basic Law for the Federal Republic of Germany) ${ }^{107}$ that offer protection other than refugee status.

\section{Article 31}

Article 31 of the Refugee Convention provides:

"1. The Contracting States shall not impose penalties, on account of their illegal entry or presence, on refugees who, coming directly from a territory where their life or freedom was threatened in the sense of Article 1, enter or are present in their territory without authorization, provided they present themselves without delay to the authorities and show good cause for their illegal entry or presence.

2. The Contracting States shall not apply to the movements of such refugees restrictions other than those which are necessary and such restrictions shall only be applied until their status in the country is regularized or they obtain admission into another country. The Contracting States shall allow such refugees a reasonable period and all the necessary facilities to obtain admission into another country."

The purpose of this article as expressed in the travaux préparatoires is to prevent refugees from being criminalised as illegal immigrants or residents of a country, since most refugees who escape from persecution are likely to enter countries of refuge without documentation. ${ }^{108}$ State practice is typically that any immigrant who enters and settles into a country without identity documents and visas is arrested, criminalised, prosecuted, sentenced and repatriated. However, the scope of article 31 of the Refugee Convention covers refugees who have entered a country unlawfully. The word "penalties" in article 31 connotes "administrative and judicial convictions" for unlawful entrance or stay in the country of refuge. ${ }^{109}$ While the phrase "coming directly" denotes refugees who arrived either from their state of origin or a nation where their existence or liberty was in danger or a third transit country where they could not obtain refugee status. ${ }^{110}$ According to Weis, the phrase "coming directly" is frequently invoked by states as a condition for the purpose of conferring asylum status and the expression "good cause" was also not elucidated. ${ }^{111}$ Weis further reiterates that article 31 (1) does not compel contracting parties to legalise the status of refugees, and it neither prohibits states from evicting them nor offers any alternatives to a refugee who has been denied asylum status and who also cannot comply with the rejection order. ${ }^{112}$

The author therefore argues that this gap in article 31 leaves a wide discretion that contracting states can depend on to reject an application for refugee status. Thus, the author argues that article 31(1) of the Refugee

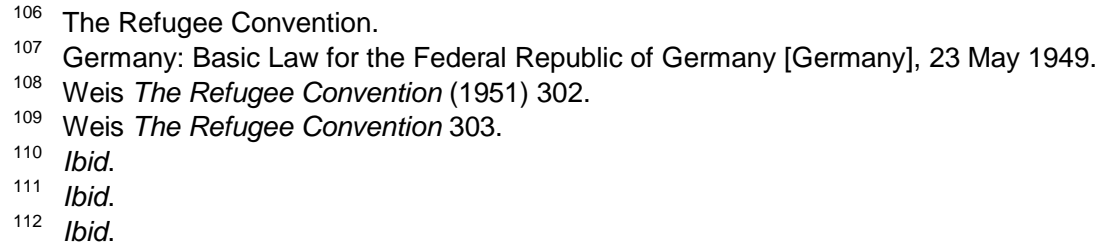


Convention should be amended to fill the lacuna. Article 31(1) also implies that refugees should not be excluded if they will be rejected by other countries and "he may not be put over the "green border"'. ${ }^{113}$ Article 31 also permits a refugee to remain in a country of transit for a short time, as may an asylum seeker whose application for legalisation is under review awaiting the determination of the application. ${ }^{114}$

However, article 31(2) provides for limitations on the movement of a refugee who has unlawfully entered or is present in a territory. Without prescribing the measure of restriction to be applied by contracting states, it states that restriction must limit their movement for national security reasons. ${ }^{115}$ With regard to the issue of custody of a refugee, the President of the Conference of Plenipotentiaries raised the issue with no response from the participants at the meeting. ${ }^{116}$ Weis submitted that refugees should not be imprisoned, but could be held for a short time in custody in refugee camps during mass arrival for the purposes of the investigation.

Weis further stated that the limitation on the movement of refugees should be until their status has been legalised or they have been granted asylum in a third country. ${ }^{118}$ This is tricky because these procedures can last from days to months and implies that refugees could be detained indefinitely. Thus, it implies vitiating the non-penalisation provided for under article 31 of the Refugee Convention and violating refugees' right to freedom of movement. Simply put, article 31(1) reveals that on no account should a refugee be punished or criminalised for unlawful entrance into a contracting state from a country where their human rights will be violated as understood by the provision of article $1 \mathrm{~A}(2)$ of the Refugee Convention. The proviso here is that the refugee will only be free from being criminalised if he or she reports to the appropriate authority of the countries without delay and adduces evidence that he or she has good reason for the unlawful entry.

In the Republic $v$ Ilola Shabani, ${ }^{119}$ two new refugees had arrived in Kaseke village in Kigoma rural district of Tanzania. They reported to the village authorities in accordance with section $9(1),{ }^{120}$ and the leadership of

113 UN Conference of Plenipotentiaries on the Status of Refugees and Stateless Persons, Conference of Plenipotentiaries on the Status of Refugees and Stateless Persons: Summary Record of the Sixteenth Meeting, 23 November 1951, A/CONF.2/SR.16,10 http://www.refworld.org/docid/3ae68cdc14.html (accessed 2018-09-27); UN Ad Hoc Committee on Refugees and Stateless Persons, Ad Hoc Committee on Statelessness and related problems, First Session: Summary record of the twentieth meeting held at Lake Success, New York, on Wednesday 1 February 1950, at 2.30. p.m., 10 February 1950, E/AC.32/SR.20 http://www.refworld.org/docidd/3ae68c1c0.html (accessed 2018-09-27); Weis The Refugee Convention 303.

114 Weis The Refugee Convention 303.

115 lbid

116 UN Conference of Plenipotentiaries on the Status of Refugees and Stateless Persons, Conference of Plenipotentiaries on the Status of Refugees and Stateless Persons: Summary Record of the Fourteenth Meeting, 22 November 1951, A/CONF.2/SR.14 http://www.refworld.org/docid/3ae68cdb0.html (accessed 2018-09-27).

117 Weis The Refugee Convention 303.

118 Weis The Refugee Convention 304.

119 Republic v Ilola Shabani, Kigoma District Court at Kigoma (unreported) Criminal Case No. 162 of 2001.

120 The Refugee Act 1998, Tanzania. 
the village handed them over to the police for onward transmission to the UNHCR. ${ }^{121}$ However, they were incarcerated for over a year and docketed as criminals who were illegitimately present in the nation. ${ }^{122}$ Also, in Adbul Rahim $v$ Minister of Home Affairs, ${ }^{123}$ the plaintiffs were denied an asylum permit and appealed against the adjudication. While the decision of the appeal was still pending, they were declared illegal immigrants and were arrested and detained in preparation for repatriation to their countries of origin.

The phrase "without delay" is problematic, because the Convention does not define this phraseology. It is submitted here that this gap gives contracting states a wide discretion to determine what constitutes "without delay". This could imply that a refugee should report to the authorities the very moment he or she steps into the host country. For instance, section $4(1)(I)$ of the South African Refugees Amendment Act, ${ }^{124}$ expects a refugee to report to a Refugee Reception Office within five days of entry into the country. This is not always practicable as South Africa has only five reception centres, spread across nine provinces, at great distances from each other. ${ }^{125}$ As a consequence, a refugee who enters the country from ports of entry without reception centres will have to go in search of a reception centre, which may take anything from one day to two months. Refugees who enter Zambia are expected to apply for asylum within seven days, ${ }^{126}$ while those who arrive in Lesotho lawfully must apply for refugee status as soon as "practicable", ${ }^{127}$ but if they come in unlawfully they must report to an immigration officer within 14 days. ${ }^{128}$ The Sierra Leone Refugees Protection Act says "as soon as possible". ${ }^{29}$ The Refugee Proclamation Act of the Federal Democratic Republic of Ethiopia says "within 15 days", 130 while Ghana allows 14 days or "as permitted by the refugee board". ${ }^{131}$ Uganda allows for 30 days.

21 Republic v llola Shabani supra.

122 Republic $v$ llola Shabani supra.

123 (965/2013) [2015] ZASCA 92 (29 May 2015).

12411 of 2017.

125 Department of Home Affairs "Cape Town Refugee Reception Office, Durban Refugee Centre, Musina Refugee Reception Centre, Port Elizabeth Refugee Reception Centre (closed to new applications) and Pretoria: Marabastad in Refugee reception centres" 2018 Department of Home Affairs http://www.dha.gov.za/index.php/contact-us/24-refugeecentres/29-pretoria (accessed 2018-09-12).

$126 \mathrm{~S}$ 11(1) of Act 1 of 2017 (Zambia).

$127 \mathrm{~S} 7$ of the Refugee Act 18 of 1983 (Lesotho).

128 S 9(2) of Act 18 of 1983 (Lesotho).

129 S 8(2) of the Refugees Protection Act 6 of 2007 (Sierra Leone).

$130 \mathrm{~S}$ 13(1) of the Refugee Proclamation No 409/2004 (Ethiopia).

131 S 8(1) of the Refugee Law, 1992 (Ghana).

132 S 19(1) of the Refugees Act 21 of 2006 (Uganda); A/CONF.2/SR.24, 27 Nov. 1951; UNHCR, Guidelines on International Protection (2003); UN Conference of Plenipotentiaries on the Status of Refugees and Stateless Persons, Conference of Plenipotentiaries on the Status of Refugees and Stateless Persons: Summary Record of the Twenty-Ninth Meeting, 28 November 1951, A/CONF.2/SR.29, http://www.refworld.org/docid/3ae68cdf4.html> (accessed 2018-09-27); UN Conference of Plenipotentiaries on the Status of Refugees and Stateless Persons: Summary Record of the Thirty-Fifth Meeting, 3 December 1951, A/CONF.2/SR.35, item 5(a) 27 and 28 Nov. and 3 Dec. 1951 http://www.refworld.org/docid/3ae68ceb4.html (accessed 2018-09-27); Weis The Refugee 
Practically, we know that it might take a refugee some time to identify the appropriate body to which to present themselves given the current state of hostility toward refugees. Sometimes, in the process of enquiry, they could also be criminalised, which will compound their problem as seen in the case of the Republic $v$ Ilola Shabani: the two refugees reported to the appropriate authority in accordance with the Refugee Act of Tanzania, but were still criminalised and detained for more than a year. Similarly, the Refugee Convention does not define what the phrase "show good cause" encompasses; this is vague.

The analysis above reveals that both articles $1 \mathrm{~F}$ and 31 are ambiguous and should be amended.

\section{CONCLUSION}

An analysis of the application of article $1 \mathrm{~F}$ of the Refugee Convention reveals that article $1 F(b)$ is unclear. Since the Refugee Convention is not clear on what constitutes a non-political crime, there are varying interpretations among contracting states as to what constitutes crimes that are non-political. This can cause challenges for asylum seekers. However, the Constitutional Court of South Africa outlines the principles and criteria for the identification of species of crime that resort to the category of political crime in order to identify crimes that are non-political.

\section{RECOMMENDATIONS}

To cure the ambiguity, the author recommends that article $1 F(b)$ of the Refugee Convention be amended. A "non-political crime" should be defined as one committed without a political intention; it must be not proportional to a political purpose, be for private benefit, and not be committed within "specific events and time". In this regard, crimes having a political objective mean crime committed to defend "fundamental human rights" - namely, the right to life, equality, human dignity, political involvement, with no discrimination because of sex or race. The political purpose must protect and promote the rule of law, liberty of individuals, faith, beliefs, views, expression, principles, and the establishment of an open and autonomous social order.

With regard to article 31 of the Refugee Convention, the author suggests an amendment; asylum seekers should be given about three months to report to the nearest appropriate body because of the mixed nature of their circumstances, which contributes to delays in submitting their applications.

Convention, 1951: The Travaux Préparatoires Analysed With a Commentary by the Late Dr Paul Weis (1995) 332; Fitzpatrick "The Post-Exclusion Phase: Extradition, Prosecution and Expulsion" 200012 International Journal of Refugee Law 272. 